\title{
Proefschrift
}

\section{Wired for Learning}

De Leng B.A. Wired for Learning - How computers can support interaction in small group learning in higher education. Universiteit Maastricht, 8 december 2009. Promotor: prof. dr. C.P.M. van der Vleuten (Maastricht); co-promotoren: dr. D.H.J.M. Dolmans (Maastricht) en dr. ir. A.M.M. Muijtjens (Maastricht). 137 pagina's. ISBN: 978-90-77201-35-0. E-mail: b.deleng@.educ.unimaas.nl

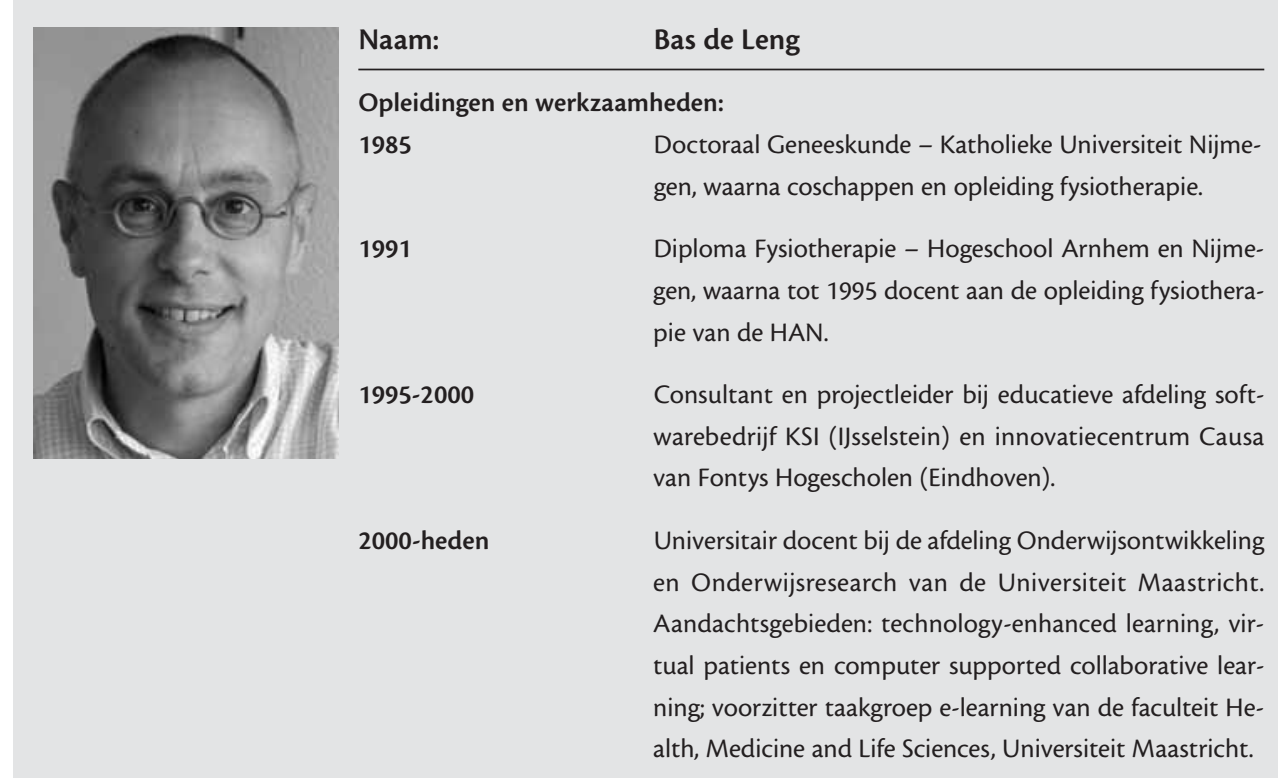

\section{Inleiding}

Technologische ontwikkelingen zoals de personal computer en het internet, gecombineerd met de opkomst van de kennismaatschappij, hebben grote invloed gehad op de manier waarop wij tegenwoordig tegen leren en werken aankijken. Opleidingsinstituten moeten steeds vaker traditionele en vertrouwde vormen van onder- wijs aanpassen om op een efficiënte en effectieve manier de kenniswerkers van de toekomst te kunnen opleiden. Het is van belang dat bij deze vernieuwingen in het onderwijs, en de manier waarop daarbij gebruik gemaakt wordt van computers, onderwijskundig en wetenschappelijk onderbouwde overwegingen een hoofdrol spelen. Dit proefschrift wil daaraan een bijdrage 
leveren en vertrekt vanuit het perspectief van actief leren in kleine groepen. De centrale onderzoeksvraag is: Hoe kunnen de interacties in kleine groepen studenten in het hoger onderwijs die samen leren met behulp van computers zo gestructureerd worden dat zij hogere cognitieve processen in gang zetten en stimuleren?

Deze vraag wordt gesteld voor verschillende sociale arrangementen waarin groepjes studenten computers gebruiken ter ondersteuning van het leren:

- 'Interactie aan de computer'-arrangementen: directe communicatie waarbij de groep fysiek aanwezig is (faceto-face-communicatie) en samenwerkt op een computer.

- 'Interactie via de computer'-arrangementen: communicatie via verschillende computers.

- Een combinatie van deze arrangementen.

\section{Het onderzoek}

In vijf studies zijn zowel kwantitatieve als kwalitatieve onderzoeksmethoden gebruikt. In het eerste onderzoek zijn studenten uit de eerste twee jaar van een opleiding geneeskunde met behulp van een schriftelijke enquête gevraagd naar hun mening over de onderlinge interacties bij het gebruik van een virtuele leeromgeving. De tweede studie betrof een focusgroeponderzoek waarin werd nagegaan welke condities bij het bestuderen van videocasus in een tutorgroep noodzakelijk zijn om productieve interacties te genereren. Daarna werd in interventiestudies bij zesdejaarsstudenten geneeskunde tijdens de coschappen gekeken hoe in 'virtuele groepen' de asynchrone communicatie via computers ingericht moet worden om hogere cognitieve processen te ondersteunen; bij deze casestudies is een combinatie van onderzoeksinstrumenten gebruikt, waaronder een inhoudsanalyse van de on- lineberichten van studenten en docent tijdens de samenwerking op afstand en interviews met studenten en docent-moderatoren over hun ervaringen met computerondersteund samenwerkend leren. In de vijfde en laatste studie is met een betrouwbaarheids- en bruikbaarheidsonderzoek nagegaan of een bestaand codeerschema voor onlinecommunicatie, de Transcript Analysis Tool, ook geschikt is voor het analyseren van 'face-to-face'groepsdiscussies. De studie beantwoordt aan de huidige behoefte aan brede analyses van zowel 'face-to-face'- als onlinecommunicatie in situaties waarin beide onderwijsvormen worden gecombineerd (blended learning).

\section{De conclusies}

De studies van dit proefschrift hebben geleid tot de volgende conclusies:

- Videocasus in het hoger onderwijs kunnen waardevol zijn voor het tot stand brengen van groepsinteracties die hogere cognitieve processen stimuleren, mits aan specifieke voorwaarden wordt voldaan.

- Videocasus moeten:

- niet te directief en niet te volledig zijn,

- goed bij de voorkennis van de studenten aansluiten,

- kortdurend en gevarieerd van ontwerp zijn en andere leermaterialen aanvullen,

- op een gestructureerde en doelgerichte manier worden bekeken, waarbij vingerwijzingen, instructies en aansporingen tot actie manieren zijn om de aandacht op de belangrijkste onderwerpen te vestigen.

- Het uitwerken van casuïstiek op de computer in groepjes is op zichzelf niet voldoende om de breedte en diepgang waarmee de studenten de casus 
bestuderen te vergroten. Het is noodzakelijk om de interacties tussen de studenten tijdens het groepsleren expliciet te structureren.

- Bij het expliciet toepassen van een methode van kritisch discussiëren (Garrison's 'Practical Inquiry Model') is een combinatie van een computerprogramma voor samenwerkend leren met een expert als moderator een goede methode voor het voeren van onlinediscussies tijdens de coschappen over concepten uit de basiswetenschappen.

- Het aangepaste Transcript Analysis Tool is een effectief en efficiënt instru- ment voor het analyseren van face-toface-communicatie in groepsbijeenkomsten van studenten met presentaties en discussies.

\section{Toekomstig onderzoek}

Toekomstig onderzoek dient zich te richten op de effecten van langdurige toepassing van scripts (instructie om de interacties tussen studenten te structureren) tijdens groepsleren en op scripts voor op afstand samenwerkende groepjes die vorm geven aan het gecombineerde gebruik van asynchrone communicatie, synchrone communicatie en andere instrumenten. 